PROBLEMS OF BIRTH DEFECTS 


\section{PROBLEMS OF BIRTH DEFECTS}

From Hippocrates to Thalidomide and After

Original papers with commentaries by

T. V. N. Persaud, MD, PhD, DSc, MRCPath, FACOG

Professor of Anatomy and Director,

Teratology Research Laboratory, University of Manitoba;

Consultant in Teratology and Pathology,

Health Sciences Centre, Winnipeg, Canada

MTP 
Published by

MTP Press Limited,

St Leonard's House,

Lancaster,

England

Copyright (C) 1977 T. V. N. Persaud

Softcover reprint of the hardcover 1st edition 1977

First published 1977

No part of this book may be reproduced in any form without permission from the publishers except for the quotation of brief passages for the purposes of review.

ISBN-13: 978-94-011-6623-2

e-ISBN-13: 978-94-011-6621-8

DOI: $10.1007 / 978-94-011-6621-8$ 


\section{CONTENTS}

\section{INTRODUCTION}

\section{ACKNOWLEDGEMENTS}

\section{BELIEFS, MYTHOLOGY, MAGIC AND SUPERSTITION}

1. Josef Warkany: Congenital malformations in the past 5

2. Mark V. Barrow: A brief history of teratology to the early 20th century 18

\section{EPIDEMIOLOGY OF BIRTH DEFEĊTS}

3. Richard L. Christiansen et al.: Classification and nomenclature of morphological defects 32

4. W. P. Kennedy: Epidemiologic aspects of the problem of congenital malformations 35

5. Alan C. Stevenson, H. A. Johnston, M. I. Patricia Stewart and Douglas R. Golding: Congenital malformations. A report of a study of series of consecutive births in 24 centres. (Extracts)

6. Paul E. Polani: The incidence of developmental and other genetic abnormalities

\section{TERATOLOGICAL MECHANISMS}

7. C. J. Roberts and R. G. Powell: Interrelation of the common congenital malformations. Some aetiological implications

8. Lauri Saxén: Defective regulatory mechanisms in teratogenesis 80

9. James G. Wilson: Mechanisms of teratogenesis $\quad 88$

10. Peter M. Dunn: Congenital postural deformities: perinatal associations 93

\section{CYTOGENETIC AND CHROMOSOMAL STUDIES}

11. Murray L. Barr and Ewart G. Bertram: A morphological distinction between neurones of the male and female, and the behaviour of the nucleolar satellite during accelerated nucleoprotein synthesis

12. Keith L. Moore, Margaret A. Graham and Murray L. Barr: The detection of chromosomal sex in hermaphrodites from a skin biopsy

13. Joe Hin Tjio and Albert Levan: The chromosome number of man

14. Joëlle Boué, André Boué and Philippe Lazar: Retrospective and prospective epidemiological studies of 1500 karyotyped spontaneous human abortions 
15. G. A. Machin: Chromosome abnormality and perinatal death

16. Hyon J. Kim, Lillian Y. F. Hsu, Sophie Paciuc, Steluta Cristian, Alicia Quintana and Kurt Hirschhorn: Cytogenetics of fetal wastage

17. Rodrigo Guerrero and Oscar I. Rojas: Spontaneous abortion and aging of human ova and spermatozoa

18. C. J. Roberts and C. R. Lowe: Where have all the conceptions gone?

19. C. O. Carter: Genetics of common disorders

20. David A. E. Shephard: Genetic hazards to man from environmental agents

\section{ENVIRONMENTAL INFLUENCES AND CONGENITAL ABNORMALITIES}

21. Fred Hale: Pigs born without eye balls

22. N. McAlister Gregg: Congenital cataract following German measles in the mother

23. Russell J. Blattner: The role of viruses in congenital defects

24. Georges Desmonts and Jacques Couvreur: Congenital toxoplasmosis. A prospective study of 378 pregnancies

25. John B. Thiersch: Therapeutic abortions with a folic acid antagonist, 4-aminopteroylglutamic acid (4-amino P.G.A.) administered by the oral route. (Extract)

26. W. Lenz: Diskussionsbemerkung von Privatdozent Dr. W. Lenz, Hamburg, zu dem Vortrag von R. A. Pfeiffer und K. Kosenow: Zur Frage der exogenen Entstehung schwerer Extremitätenmissbildungen

27. W. G. McBride: Thalidomide and congenital abnormalities

28. W. Lenz: Thalidomide and congenital abnormalities

29. W. Lenz and K. Knapp: Foetal malformations due to thalidomide

30. Edgar Grunwaldt and Talcott Bates: Nonadrenal female pseudohermaphrodism after administration of testosterone to mother during pregnancy

31. Lawson Wilkins: Masculinization of female fetus due to use of orally given progestins

32. Arthur L. Herbst, Howard Ulfelder and David C. Poskanzer: Adenocarcinoma of the vagina. Association of maternal stilbestrol therapy with tumor appearance in young women

33. D. Janz and U. Fuchs: Are anti-epileptics harmful in pregnancy? (Extract)

34. S. R. Meadow: Anticonvulsant drugs and congenital abnormalities

35. S. R. Meadow: Congenital abnormalities and anticonvulsant drugs

36. Sumner J. Yaffe: A clinical look at the problem of drugs in pregnancy and their effect on the fetus

37. Laman Amin-Zaki, Sami Elhassani, Mohamed A. Majeed, Thomas W. Clarkson, Richard A. Doherty and Michael Greenwood: Intra-uterine methylmercury poisoning in Iraq

38. Joan M. Spyker: Assessing the impact of low level chemicals on development: behavioral and latent effects

39. Winea J. Simpson: A preliminary report of cigarette smoking and the incidence of prematurity. (Extract)

40. C. R. Lowe: Effect of -mothers' smoking habits on birth weight of their children

41. Kenneth L. Jones and David W. Smith: The fetal alcohol syndrome

42. James H. Renwick, Anne M. Possamai and Madeleine R. Munday: Potatoes and spina bifida

43. Douglas P. Murphy: The outcome of 625 pregnancies in women subjected to pelvic radium or roentgen irradiation. (Extract)

44. Joseph Sternberg: Radiation and pregnancy 


\section{DETECTION OF ENVIRONMENTAL TERATOGENS}

45. T. V. N. Persaud: Environmental factors in the etiology of human malformations: perspectives and problems of evaluation

46. Richard Doll: Hazards of the first nine months: an epidemiologist's nightmare

\section{PRENATAL DIAGNOSIS AND MANAGEMENT OF CONGENITAL}

\section{ABNORMALITIES}

47. Aubrey Milunsky and Leonard Atkins: Prenatal diagnosis of genetic disorders. An analysis of experience with 600 cases

48. Stanley J. Birnbaum: Prenatal diagnosis of mongolism by X-ray

49. Rigoberto Santos-Ramos and Johann H. Duenhoelter: Diagnosis of congenital fetal abnormalities by sonography

50. John T. Queenan and Enrique C. Gadow: Amniography for detection of congenital malformations

51. Kaoru Suzumori and Yoshiaki Yagami: Diagnosis of human fetal abnormalities by fetography

52. Alan E. H. Emery: Genetic counselling-or what can we tell parents? 348

53. B. Hagberg: Pre-, peri- and postnatal prevention of major neuropediatric handicaps 354

\section{SOCIAL, ETHICAL, AND MEDICO-LEGAL PROBLEMS}

54. John Fletcher: Moral and ethical problems of pre-natal diagnosis

55. John Fletcher: Attitudes toward defective newborns

56. R. B. Zachary: Ethical and social aspects of treatment of spina bifida

57. Raymond S. Duff and A. G. M. Campbell: Moral and ethical dilemmas in the specialcare nursery 


\section{INTRODUCTION}

Surprisingly, the beginning of a modern approach to the problems of birth defects is relatively recent and dates from Gregg's classical report in 1941 that mothers who contracted rubella during the first trimester of pregnancy gave birth to infants with severe multiple anomalies. For the first time, an environmental agent was found to be teratogenic in man and was documented in a thoroughly convincing manner. Since then, many important discoveries and significant developments have been made, particularly in the areas of environmental teratogenesis, hereditary mechanisms, and prenatal diagnosis.

In recent years, there has been an impressive surge of interest in the causes and prevention of birth defects. Undoubtedly this resulted not only from the thalidomide tragedy, but also from the steady decline in infant mortality from other causes, such as infectious and nutritional diseases. The magnitude of the problem is emphasized by a recent report which estimated that at least $6 \%$ of all infants are born with some genetic or developmental anomaly. Furthermore, congenital defects contribute to approximately $20 \%$ of all neonatal mortality.
This collection of articles and commentaries is an integration of information from many disciplines, and presents a comprehensive survey of both recent and previously reported work related to the major aspects of birth defects. In particular, an attempt has been made to provide a critical assessment of current concepts and to identify areas in need of further investigation.

The scope of this volume and space limitations precluded discussion of and reference to all papers of relevance or importance: a work of the present nature must necessarily be selective. Some good papers have been left out or given relatively little consideration. It is my hope that the list of Further References will be consulted and should compensate for this lack of completeness. The important milestones in the investigation of birth defects are highlighted by the inclusion of the original reports or extracts from them. In some cases, however, more recent articles have been given preference to original scientific papers. These have been selected primarily for their appropriateness and depth of interpretation. 


\section{ACKNOWLEDGEMENTS}

I am greatly indebted to the authors, editors, and publishers who have granted permission to reprint previously published articles. It is a special pleasure for me to acknowledge their cooperation in making this work possible.

Several colleagues have made valuable suggestions with respect to the commentaries; I am, however, especially grateful to Dr K. L. Moore, Professor and Chairman of the Department of Anatomy, University of Toronto; Dr M. Ray, Associate Professor of Anatomy and Pediatrics (Genetics), University of Manitoba; Dr J. B. Hyde, Associate Professor of Anatomy, University of
Manitoba; and my graduate student Ms Lois A. Kennedy.

I wish to thank Mr P. M. Lister, Managing Editor, MTP Press .Limited, not only for his advice on editorial matters, but also for providing the original impetus in this undertaking.

Thanks are also due to Mrs Roberta Van Aertselaer for her splendid secretarial help and to Ms Brenda Bell for preparing excellent photographic copies of several articles.

Finally, I am indebted to my wife, Gisela, for her patience and understanding which have been a constant source of encouragement. 